\title{
WAVE ENERGY POTENTIAL ALONG THE GULF OF GUINEA COAST OF NIGERIA
}

Original scientific paper

UDC: 532.593:551.466

https://doi.org/10.18485/aeletters.2019.4.4.4

\author{
Olakunle Kayode ${ }^{1}$, Olufemi A. Koya² \\ ${ }^{1}$ Department of Mechanical Engineering, Osun State University, Osogbo, Nigeria \\ ${ }^{2}$ Department of Mechanical Engineering, Obafemi Awolowo University, Ile-Ife, Nigeria
}

\begin{abstract}
:
Nigeria is currently experiencing energy deficit in terms of electrification. Development of renewable energy sources such as Sea wave energy may help augment this deficit. This paper set to investigate wave energy potential of the coast of Nigeria. Data required for estimating the wave energy potential of the coastal waters of Nigeria were obtained from WAVEWATCH II $^{\odot}$ wave generation model. The wave climate data were analyzed using basic statistical analysis such as average, mean, and range. Due to the scarcity of reliable measured wave climate data, an effort was made to investigate the relationship the mean monthly wave power may have with mean monthly rainfall. Establishing a good level of correlation will provide an alternative mean of forecasting wave power for the coastal

region. The results show that the mean annual wave power magnitude generally decreases from the west coast (at $10.74 \mathrm{~kW} / \mathrm{m}$ ) to the east coast (at $5.64 \mathrm{~kW} / \mathrm{m}$ ) for the reference points considered. The most energetic months occurs during the rainy season while the least energetic months occur during the dry season. There is a strong positive correlation between mean monthly wave power and mean monthly rainfall at $5 \%$ significant level.
\end{abstract} ARTICLE HISTORY

Received: 26.09.2019.

Accepted: 04.12.2019.

Available: 31.12.2019.

\section{INTRODUCTION}

The electrification rate for Nigeria in 2016 was $61 \%$ while people without access to electricity in the same year were 74 millions [1]. With this energy deficit, it has been suggested that the country must focus on the development of renewable and sustainable energy sources [2]. For many rural communities, geographical factors, such as remoteness from major urban centers, as well as difficult terrain, make accessibility difficult. This also have negative impact on the ease of connection to the grid. For example the coastal communities of Ayetoro and Mahin in the western part of the coast were electrified and even with grid connection, [3] reported that the supply is highly erratic and undependable. It was reported by [4] that in Ayetoro, the community has made provision for a generator which runs for certain number of hours during the day. However, this provision was faulted as they asserted that the cost of individual power generating sets in homes increases the level of risk to lives and properties in communities as most of such sets are powered by highly inflammable petrol (gasoline). An attractive solution to this problem in coastal communities is to utilize sources of renewable energy in their immediate environment. Sea waves appear to be the most appropriate due to its special advantages over solar and wind. It is relatively predictable and consistent especially in the tropical regions when compared to wind or solar. The key characteristic of sea waves is their high energy density, which is the highest among renewable energy sources [5]. It is available $90 \%$ of the time at a given site, compared to solar and wind energies which are 
available $20-30 \%$ of the time [6]. Capturing energy from waves is complex and very location specific. In general, there are three main types of wave energy systems: Shoreline devices, (0-10m deep), Near-shore devices (10-25m) and Offshore devices (more than $40 \mathrm{~m}$ ) $[7,8]$. The wave energy harvesting should start with the proper characterization of available wave energy resources in a given area [9]. Thus, the first step is to determine the wave energy potential of the Nigerian coast. However, reliable long term measured wave climate data are generally not available for the Gulf of Guinea (a section of the Atlantic Ocean on which Nigeria coast is located). The wave climate potential data is crucial to formulating the appropriate wave energy converter device that can best utilize the available wave energy resources as well as gives insight to best locations for the device.

Ocean Wave energy is mostly derived from a transfer of wind energy to the surface of the ocean [7]. Sea waves are not pure sinusoids. Water wave motions are complex and irregular on the ocean surface. The wave crests in the ocean are slightly sharper and the troughs are slightly flatter. In a given region, the wave parameters such as height, wavelength, and the period are functions of wind speed and fetch [10]. In real sea-state, the wave height and period are two measurable properties of ocean surface waves. These properties are measured by using wave gauges or estimated by sight. The available wave power density, $\mathrm{P}(\mathrm{W} / \mathrm{m})$, in each meter of crest length for deep water in a more detailed form is given by [11] as:

$$
\mathrm{P}=\frac{\rho g^{2} H_{S T}^{2}}{64 \pi}
$$

Where $\rho$ is the density of the sea water in $\mathrm{kg} / \mathrm{m}^{3}, g$ is the acceleration due to gravity in $\mathrm{m} / \mathrm{s}^{2}$, $\mathrm{H}_{\mathrm{s}}$ is the significant wave height in $\mathrm{m}$, and $T_{e}$ is the mean wave period in seconds. It is significant to note that wave power varies with the square of wave height, and proportional to unit increase in wave period.

\section{THE STUDY AREA}

The Nigerian coastal zone lies within Lat $4^{\circ} 10^{\prime}$ to $6^{\circ} 20^{\prime} \mathrm{N}$ and Longitudes $2^{\circ} 45^{\prime}$ to $8^{\circ} 35^{\prime} \mathrm{E}$ spanning about $853 \mathrm{~km}$ of low-lying coastline [12]. The coast is bordered by a portion of the continental shelf (less than $200 \mathrm{~m}$ deep) of the Gulf of Guinea. The shelf widths range from $15 \mathrm{~km}$ in the west to about $67 \mathrm{~km}$ in the Niger Delta and about $87 \mathrm{~km}$ off the Cross River estuary in the East as shown in Fig.1.

\subsection{Coastal sectors}

The Nigerian coastline for the purpose of this study was divided into three sectors: West coast, (Niger) Delta coast, and the East coast (Fig.1). For each sector, a wave data extraction points were defined as shown in Table 1. This approach of analyzing wave climate for an extensive coast line based on division into sectors is similar to that employed by [13].

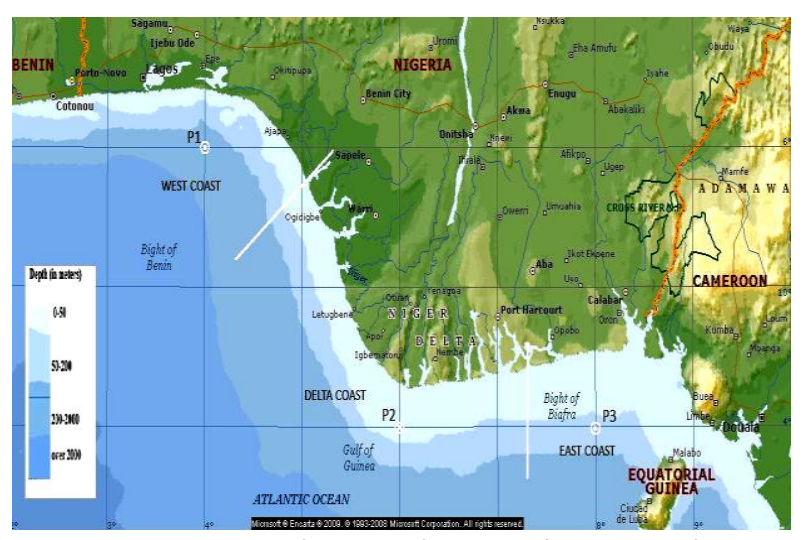

Fig. 1. Nigeria coastal water showing the sector divisions with the grid points used in the analysis (background map: Microsoft Encarta, 2009)

Table 1: Coastal Sectors Wave Data Extraction Points and their nearest Land Based Weather Stations

\begin{tabular}{|l|c|c|c|c|c|}
\hline Sector & $\begin{array}{c}\text { Ref. } \\
\text { Point }\end{array}$ & Long. & Lat & $\begin{array}{c}\text { Dist. to } \\
\text { shore (km) }\end{array}$ & $\begin{array}{c}\text { Weather } \\
\text { station }\end{array}$ \\
\hline $\begin{array}{l}\text { West } \\
\text { Coast }\end{array}$ & $\mathrm{P} 1$ & $4^{\circ} 00^{\prime} \mathrm{E}$ & $6^{\circ} 00^{\prime} \mathrm{N}$ & 47.3 & Lagos \\
\hline $\begin{array}{l}\text { Delta } \\
\text { Coast }\end{array}$ & $\mathrm{P} 2$ & $6^{\circ} 00^{\prime} \mathrm{E}$ & $4^{\circ} 00^{\prime} \mathrm{N}$ & 32.2 & Brass \\
\hline $\begin{array}{l}\text { East } \\
\text { Coast }\end{array}$ & $\mathrm{P} 3$ & $8^{\circ} 00^{\prime} \mathrm{E}$ & $4^{\circ} 00^{\prime} \mathrm{N}$ & 60.3 & Eket \\
\hline
\end{tabular}

\section{METHODOLOGY}

This section described the methodology employed in this work.

\subsection{Nigeria Offshore Wave Power Resources Estimation}

Data required for estimating the wave energy potential of the coastal waters of Nigeria were obtained from the National Oceanic and Atmospheric Administration (NOAA)/ National Center for Environmental Prediction (NCEP) wave generation model WAVEWATCH III ${ }^{\odot}$. The following 
variables are available in the dataset: wind direction (degrees, meteorological convention), wind speed $(\mathrm{m} / \mathrm{s})$, significant wave height $(\mathrm{m})$, peak wave direction (degrees, meteorological convention) and peak wave period (s). The data is provided in an excel spreadsheet and in comma delineated text format. However, for the purpose of this work, significant wave height, period and wave direction, spanning the period from February, 2010 to February, 2015, were extracted from the dataset. Moreover, wave climate forecast for each of the reference data extraction points were monitored and recorded from the website, www.buoyweather.com on daily basis for a period of one year commencing from $1^{\text {st }}$ November, 2017 and ending on $31^{\text {st }}$ October, 2018.

\subsection{Accuracy of data}

The modeled data obtained from WAVEWATCH III ${ }^{\odot}$ were compared with some available historic data measured directly by the Nigerian Institute for Oceanographic and Marine Research (NIOMR). The organization is responsible for oceanographic research and data acquisition in Nigeria, but do not have continuously measured wave parameters covering an extended period in time for any location along the entire coast of Nigeria. The comparison established the reliability of the WAVEWATCH III ${ }^{\odot}$ hind cast data.

\subsection{Analysis of wave data}

In order to determine the energy flux of a complex sea state, two physical quantities were used: significant wave height, and energy period. For real sea state the wave energy flux $(\mathrm{J}$, in $\mathrm{W} / \mathrm{m})$ in a given wave front in deep water is given, in simplified form by $[14,15]$ as,

$$
\mathrm{J}=k T_{e} H_{s}^{2}
$$

where $k$ is given as $500 \mathrm{~W} / \mathrm{s} \mathrm{m}^{3}$.

The wave climate data were analyzed using basic statistical analysis such as average, mean, and range for the significant wave height and period.

\subsection{Mean monthly wave power and mean monthly rainfall relationship}

Due to the scarcity of reliable wave climate data, an effort was made to investigate the relationship the mean monthly wave power may have with mean monthly rainfall. Establishing a good level of correlation between the two will provide an alternative means of forecasting wave power for the coastal region. The mean monthly rainfall data was obtained from www.en.climate-data.org for land based locations nearest to each wave data extraction points. The selected locations were Lagos (West coast sector), Brass (Niger Delta coast sector), and Eket (East coast sector) (see Appendix for the mean monthly rainfall data for each location). These were the closest land based weather stations to the respective data extraction points for each sector (Table 1). The two set of data were analyzed using regression analysis.

\subsection{Bathymetry profile}

The bathymetric profile typical of each sector was plotted using Google earth. Google earth is a virtual globe, map and geographical information program produced by Google. The profile axes used are as presented in Table 2. The plot data points for the profiles were obtained by placing the cursor on any point of interest on the map while parameters such as altitude (in this case depth), longitudinal and latitudinal location as well as distance relative to another point can then be read off the screen.

Table 2: Bathymetry Profile Axis Reference Points

\begin{tabular}{|c|c|c|c|c|}
\hline $\begin{array}{c}\text { Profile } \\
\text { Axis }\end{array}$ & \multicolumn{2}{|c|}{ Shore line point } & \multicolumn{2}{c|}{ Off-shore point } \\
\cline { 2 - 5 } & Long. & Lat. & Long. & Lat. \\
\hline $\begin{array}{c}\text { West } \\
\text { Coast }\end{array}$ & $4^{\circ} 33^{\prime} \mathrm{E}$ & $6^{\circ} 17^{\prime} \mathrm{N}$ & $4^{\circ} 20^{\prime} \mathrm{E}$ & $6^{\circ} 05^{\prime} \mathrm{N}$ \\
\hline $\begin{array}{c}\text { Delta } \\
\text { Coast }\end{array}$ & $6^{\circ} 03^{\prime} \mathrm{E}$ & $4^{\circ} 16^{\prime} \mathrm{N}$ & $5^{\circ} 50^{\prime} \mathrm{E}$ & $4^{\circ} 04^{\prime} \mathrm{N}$ \\
\hline $\begin{array}{c}\text { East } \\
\text { Coast }\end{array}$ & $7^{\circ} 59^{\prime} \mathrm{E}$ & $4^{\circ} 32^{\prime} \mathrm{N}$ & $7^{\circ} 59^{\prime} \mathrm{E}$ & $4^{\circ} 16^{\prime} \mathrm{N}$ \\
\hline
\end{tabular}

\section{RESULTS AND DISCUSSION}

The results of the mean monthly wave height, Bathymetry profile as well as mean monthly wave power for each of the selected wave data extraction points representing the three coastal divisions considered in this study are presented separately for the west, delta, and east coasts respectively.

\subsection{West coast wave climate}

Graphs showing typical bathymetric profile of the west coast, mean monthly significant wave height $\left(H_{s}\right)$, and the mean monthly wave power for 
the reference point $P 1$ located in the west coast region are as presented in Fig.2 (a-c) respectively. The sea floor profile revealed that the shore line zone extends up to $3 \mathrm{~km}$ from the beach into the sea, while near-shore zone extends from 3 to $7 \mathrm{~km}$ from beach beyond which the off shore zone commenced. The average sea floor slope for the profiled section is $1 / 76$. The lesser the gradient, the wider the continental shelf and the slower the translation to off-shore water. This translated to near- shore waters being 2.5 to $6 \mathrm{~km}$ from the shore (Fig.2a).

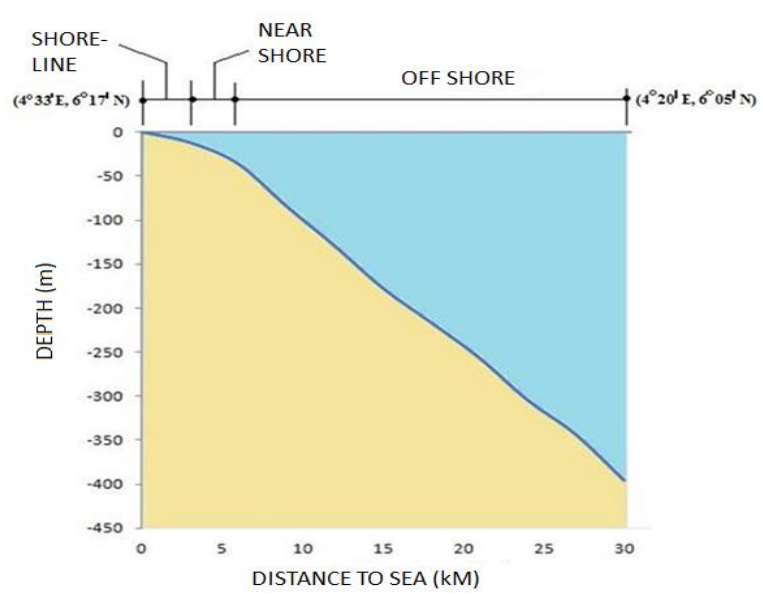

(a)

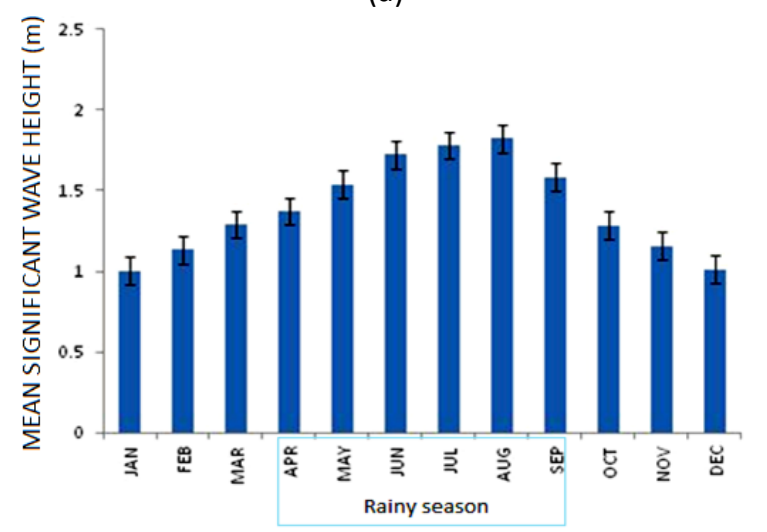

(b)

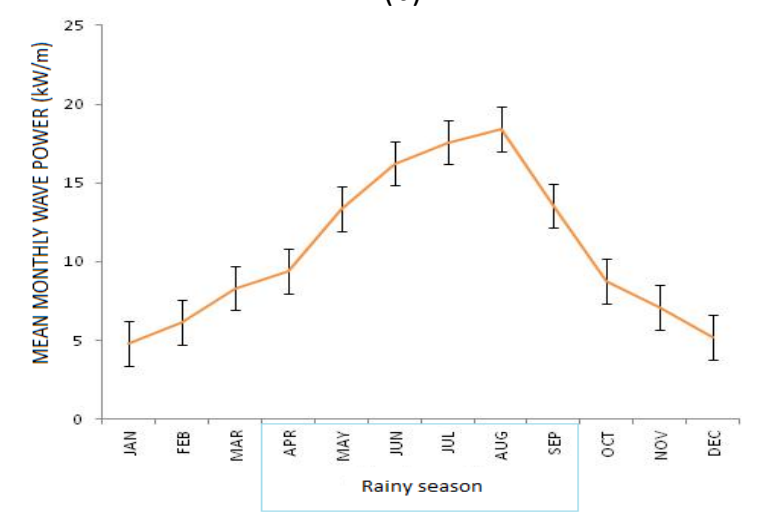

(c)

Fig.2. Typical west coast (a) bathymetry profile; (b) monthly mean significant wave height; (c) mean monthly wave power
The mean monthly significant wave height ranges from a minimum of $1.003 \mathrm{~m}$ in January to a maximum of $1.824 \mathrm{~m}$ in August. The mean monthly wave power varies from a minimum of $4.78 \mathrm{~kW} / \mathrm{m}$ (in January) to a maximum of $13.42 \mathrm{~kW} / \mathrm{m}$ (August). The mean annual wave power for the reference point is $10.74 \mathrm{~kW} / \mathrm{m}$. This is within the range of mean annual wave power potential for the region usually depicted in global wave climate maps $[16,17]$. For the west coast immediate hinterland, the raining season began around March/April and ended around September/ October, with the rainiest month being June (Appendix). The prevailing wind over the hinterland during this period is the South West wind which originated far away in the Atlantic Ocean. This wind is moisture laden and responsible for the rainfall during this period. For the rest of the year, the prevailing wind over the hinterland is the North-east wind (known as Harmattan). This period constituted the dry season period for the region.

A comparison of the mean monthly wave power pattern across the calendar months with the rainfall pattern (Appendix) for the immediate hinterland (Lagos) shows that the most energetic months falls within the raining season, while the least energetic months falls within the dry season. Hence, the wave power pattern in the west coast appears to be seasonal in nature.

\subsection{Delta coast wave climate}

The typical sea floor profile, mean monthly significant wave height $\left(\mathrm{H}_{\mathrm{s}}\right)$, and the mean monthly wave power for the reference point P2 located in the delta coast region are as presented in Fig. $3(\mathrm{a}-\mathrm{c})$ respectively. The sea floor profile revealed that the shore line zone extends up to $4 \mathrm{~km}$ from the beach into the sea, while near-shore zone extends from 4 to $9 \mathrm{~km}$ from beach beyond which the off shore zone commenced. The average sea floor slope for the profiled section is $1 / 105$. The mean monthly significant wave height ranges from a minimum of $0.935 \mathrm{~m}$ in January to a maximum of $1.74 \mathrm{~m}$ in July. The mean monthly wave power varies from a minimum of $4.28 \mathrm{~kW} / \mathrm{m}$ (in January) to a maximum of $16.37 \mathrm{~kW} / \mathrm{m}$ (July). The mean annual wave power for the reference point was $9.73 \mathrm{~kW} / \mathrm{m}$. Again like the west coast; this value is within the range of mean annual wave power potential for the Nigeria coastal region as a whole as usually depicted in global wave climate maps $[16,17]$.For the immediate hinterland of Delta coast, the raining season began around March and ended 
around the month of November, with the rainiest month being June. The prevailing wind over the hinterland during this period is the South West wind. The dry season is shorter, spanning the period from December to March. Similarly, the wave power pattern for the region's reference point also reflected seasonal rhythm of the rainfall pattern for the region's immediate hinterland with the rainy season corresponding with the months having the highest mean monthly wave power.

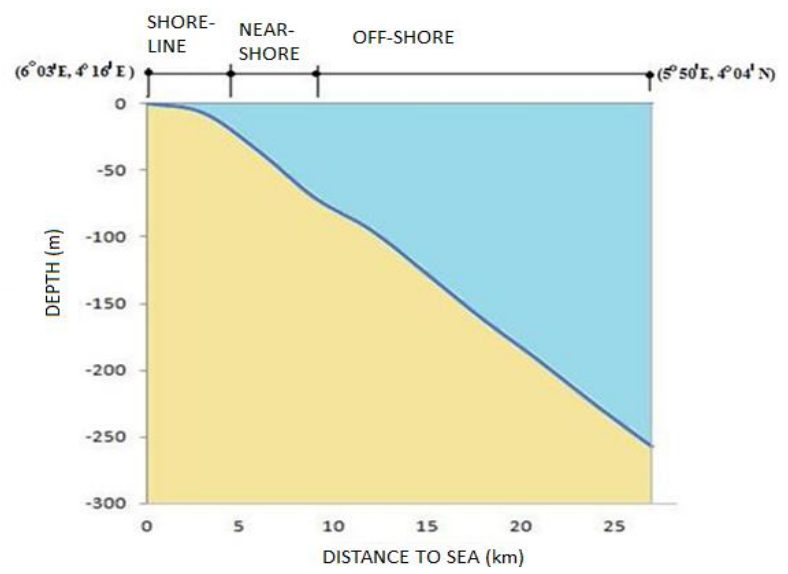

(a)

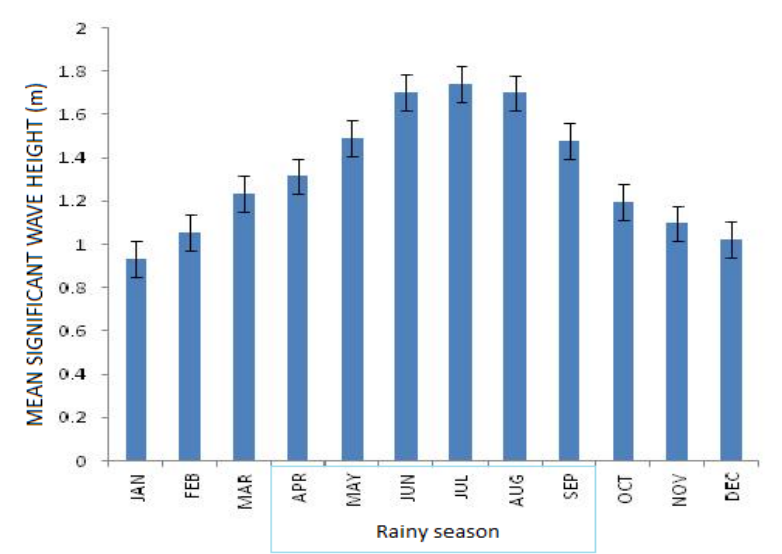

(b)

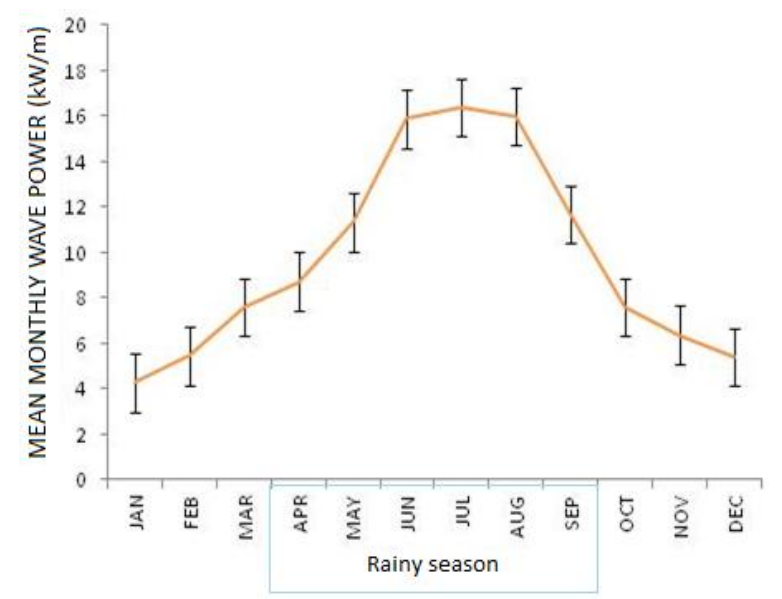

(c)

Fig.3. Typical Delta coast (a) bathymetry profile; (b) monthly mean significant wave height; (c) mean monthly wave power

\subsection{East coast wave climate}

The graphs showing a typical sea floor profile of the East coast mean monthly significant wave height, and the mean monthly wave power for the reference point P3 located in the East coast region is as presented in Fig.4 (a-c), respectively. The sea floor profile revealed that the shore line zone extends up to $11 \mathrm{~km}$ from the beach into the sea, while near-shore zone extends from $11 \mathrm{~km}$ onward beyond the $35 \mathrm{~km}$ distance covered by the profile. The average sea floor slope for the profiled section is $1 / 1034$. This progressive increase in width of each zone as well as increasing shallowness of the sea depth as we moves from the west to the east is the reflection of the widening of the continental shelf from the west coast to the east coast. The mean monthly significant wave height range from a minimum of $0.711 \mathrm{~m}$ in January to a maximum of $1.26 \mathrm{~m}$ in July. The mean monthly wave power varies from a minimum of $2.477 \mathrm{~kW} / \mathrm{m}$ (in January) to a maximum of $8.598 \mathrm{~kW} / \mathrm{m}$ (July). The mean annual wave power for the reference point was $5.64 \mathrm{~kW} / \mathrm{m}$. Compared to the first two regions, the mean annual power for the reference point of this region was significantly below the mean annual wave power for the coastal region of Nigeria $[16,17]$.

Although the rainfall season also coincide with months with the highest mean monthly wave pattern, as was similarly observed for the two previous regions, the huge discrepancy observed between global mean annual wave power for the Gulf of Guinea as a whole and the East coast do not appear to have connection with the rainfall pattern, but, rather with the physical geography of the region. From the sea profile patterns, it was observed that the gradient of the sea floor decreases from the west coast towards the east coast. The east coast also had the shallowest sea floor among the three regions. A study of the bathymetry profiles shows that the continental shelf is narrower in the west coast and broadest in the east coast. When water waves enter relatively shallower water, the wave amplitude tends to decrease and consequently their energy content. Moreover, the East coast is partially obstructed from the open sea by the presence of the Bioko Island of Equatorial Guinea (see Fig.5). This has a breakwater effect, that is, a situation where wave height is greater at the wave approach side of a physical barrier and lowers in the waters at the other side of the barrier. To visualize the variation of wave energy potential along the coast, the 
mean annual power level for each of the reference points as well as the prevailing wave direction is as depicted in Fig.5. The figure shows that the wave power magnitude generally decreases from the west coast to the east coast, of interest too is the fact that the continental shelf (sea depth less than $200 \mathrm{~m}$ ) increases from the west to the east with transitional distance from shore to deep ocean (beyond continental shelf) being relatively shorter in the west and longer in the east. Due to the relatively longer distance from the shore to the near shore zone coupled with a comparatively low mean annual wave power, the economical feasibility of taping the wave power of the east coast is poor and its extraction is not advisable.

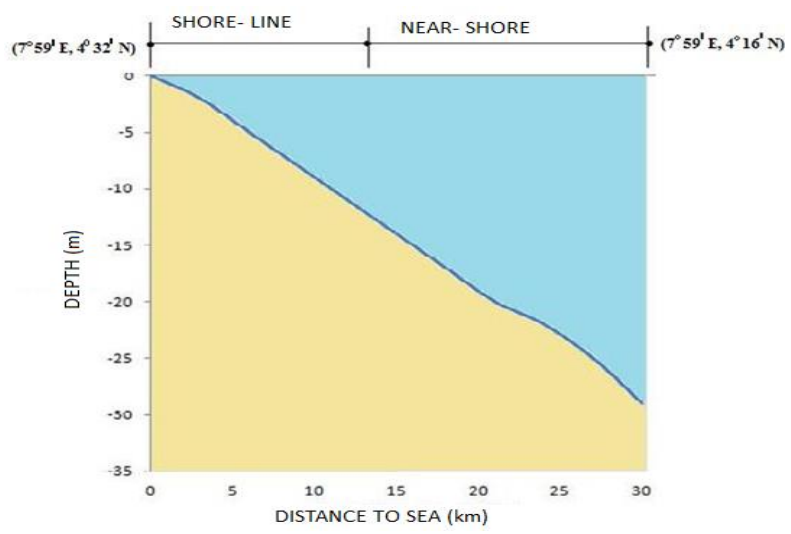

(a)

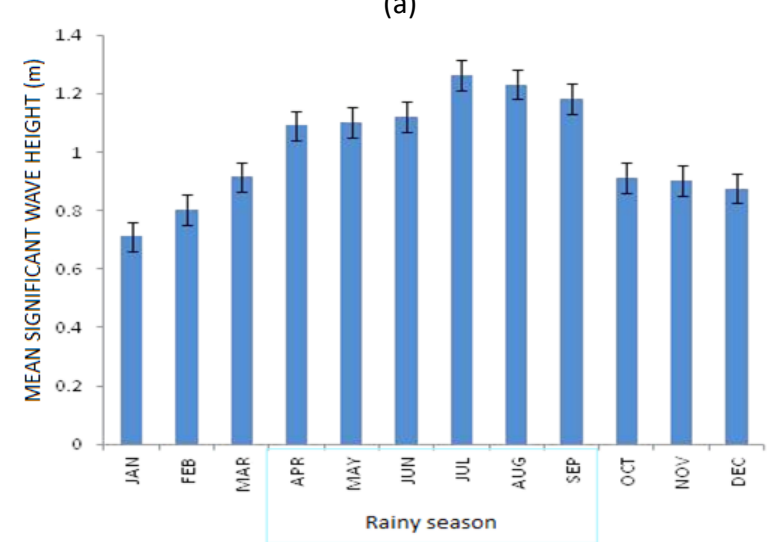

(b)

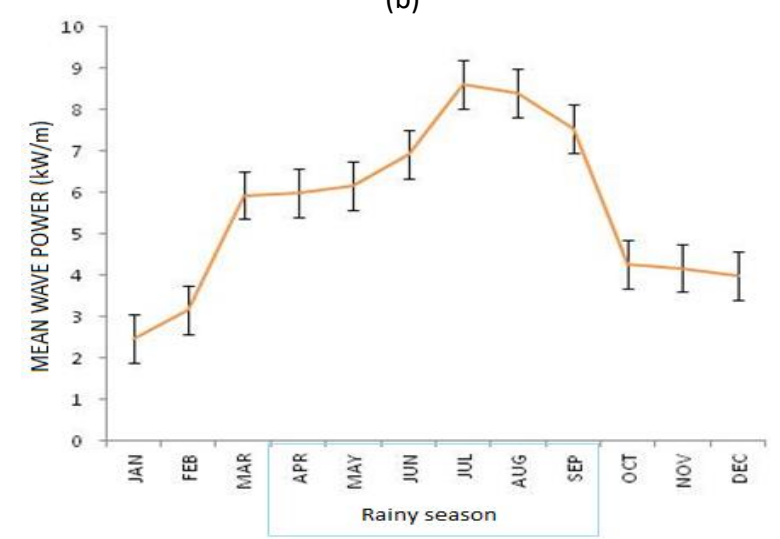

(c)

Fig.4. Typical East coast (a) bathymetry profile; (b) monthly mean significant wave height; (c) mean monthly wave power

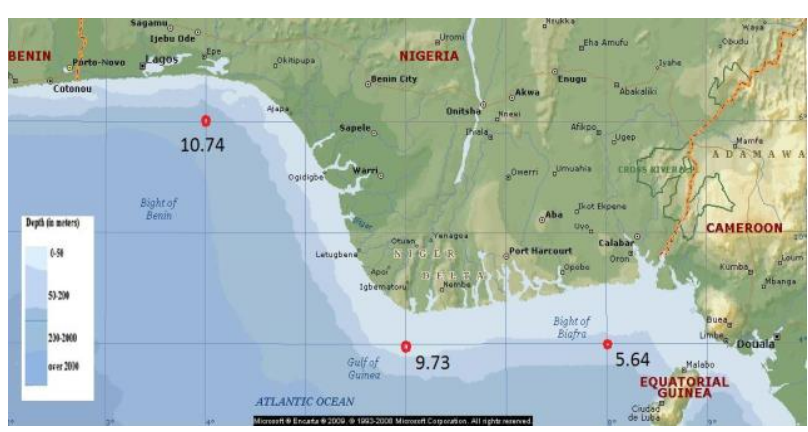

Fig.5. Mean annual wave power levels (in $\mathrm{kW} / \mathrm{m}$ ) at the selected reference points based on analyzed wave data (background map from Microsoft Encarta, 2009)

\subsection{Mean monthly wave power and mean monthly rainfall relationship}

As observed in the immediate previous subsections, the rainfall pattern of the immediate hinterland of the coast bore a similarity with the wave power pattern observed in term of the pick and lowest magnitudes of the respective parameters of measurement. Therefore, the mean monthly wave power was correlated with the mean monthly rainfall for a land ward rain measuring station nearest to the wave power data sites. The mean monthly wave power correlated with mean monthly rainfall for same periods are as presented in Fig. 6 (a-c) respectively for the West, Delta, and the East coast regions. The mathematical relationship between the two parameters for the West, Delta, and the East coast regions are as detailed in Eqns. 3, 4, and 5, respectively:

$$
\begin{aligned}
& P_{w}=0.0418 R_{f}+5.456 \\
& P_{w}=0.0295 R_{f}+3.468 \\
& P_{w}=0.0125 R_{f}+2.839
\end{aligned}
$$

Where $P_{w}$ is the mean monthly wave power (in $\mathrm{kW} / \mathrm{m}$ ) and $R_{f}$ is the mean monthly rainfall (in $\mathrm{mm}$ ). The correlation coefficient for the West, Delta, and the East coast regions are 0.807, 0.817, and 0.874 respectively, at $5 \%$ significant level. The results imply a good positive correlation between mean monthly wave power and mean monthly rainfall. Even though the coefficient of the rainfall term decreases from west to east, the total annual rainfall decreases from east to west (Appendix). The power magnifying effect the increase in rainfall would have had was mitigated by the sheltered and shallow nature of the east coast. Moreover, the rainfall pattern along the Nigerian coast is driven by south west wind. 


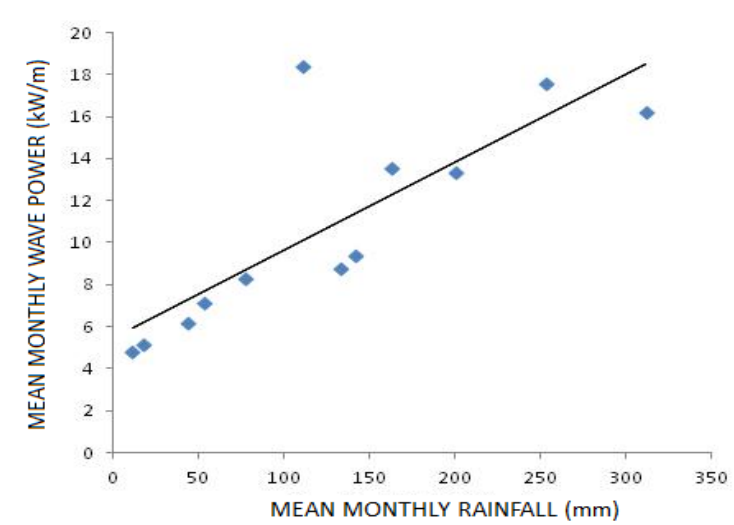

(a)

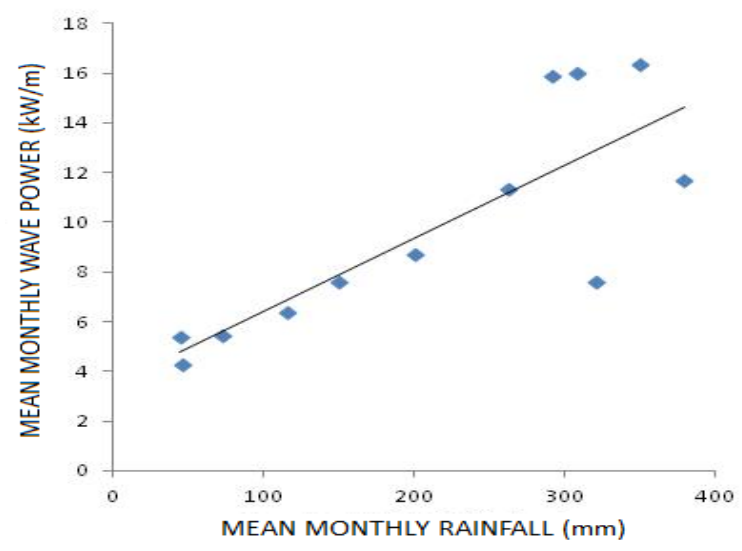

(b)

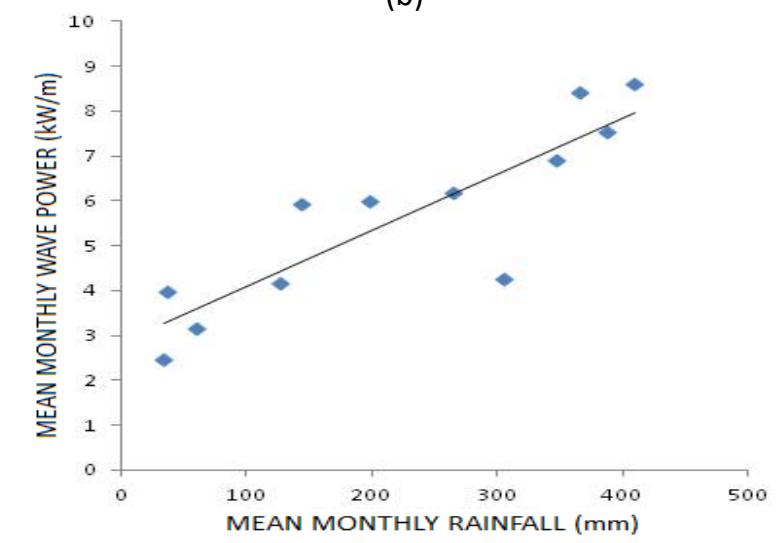

(c)

Fig.6. Mean monthly wave power and mean monthly rainfall relationship (a) West coast; (b) Delta coast; (c) East coast
The wind is strongest in the six month period from May through October which corresponds to the rainy season for the region. The wind is also responsible for the generation of the coastal waves since the greater parentage of ocean waves are wind generated. Finally, the constant terms of Equations 3-5 represents the minimum mean monthly wave power when rainfall is negligible i.e. during the dry season. These values also decreases from west to east implying that apart from rainfall, other factor(s) are at play in wave power trend across the entire length of the coast, possible factor include coastal topography as well as bathymetry pattern.

\section{CONCLUSIONS}

The mean annual wave power magnitude generally decreases from the west coast (at 10.74 $\mathrm{kW} / \mathrm{m}$ ) to the east coast (at $5.64 \mathrm{~kW} / \mathrm{m}$ ) for the reference points considered for each of the coastal sectors. The most energetic months occurs during the rainy season and peak around the middle of the season while the least energetic months occur during the dry season. There is a strong positive correlation between mean monthly wave power and mean monthly rainfall at $5 \%$ significant level.

\section{APPENDIX [18]}

\begin{tabular}{|l|c|c|c|c|c|c|c|c|c|c|c|c|}
\hline \multicolumn{10}{|c|}{ MEAN MONTHLY PRECIPITATION/RAINFALL $(\mathrm{mm})$} \\
\hline STATION & J & F & M & A & M & J & J & A & S & O & N & D \\
\hline LAGOS & 25 & 43 & 97 & 140 & 251 & 386 & 248 & 74 & 161 & 177 & 70 & 21 \\
\hline BRASS & 64 & 104 & 171 & 261 & 379 & 610 & 494 & 295 & 499 & 417 & 197 & 81 \\
\hline EKET & 33 & 74 & 151 & 227 & 267 & 412 & 505 & 411 & 465 & 363 & 161 & 50 \\
\hline
\end{tabular}

\section{REFERENCES}

[1] REN21. Renewables 2018 Global Status Report. Paris: REN21 Secretariat, 2016.

https://www.ren21.net/wpcontent/uploads/201 9/08/full-report-2018.pdf\&sa (accessed 19 Aug 2019)
[2] S.O. Oyedepo, Energy and sustainable development in Nigeria: The way forward. Energy, Sustainability and Society, 2 (1) 2012: 117 https://doi:10.1186/2192-0567-2-15

[3] O. Olufayo, F. Omole, T. Lawanson, Utilizing Creeks for Integrated Rural Coastal Development 
of Ilaje Area of Nigeria. Ethiopian Journal of Environmental Studies and Management, 6 (3) 2013: 294-299.

http://dx.doi.org/10.4314/ejesm.v6i3.10

[4] A.A. Emmanuel, T. Akinbode, Communal Facilities in Coastal Settlements of Ondo State, Nigeria: Assessment of Community-Based Organisations' Efforts Using the Facility Contributory Index Model. British Journal of Education, Society \& Behavioural Science, 2 (2), 2012: 150 - 161.

https://doi.org/10.9734/BJESBS/2012/1084

[5] A. Clément, P. McCullen,, A. Falcão, A. Fiorentino, F. Gardner, K. Hammarlund, G. Lemonis, T. Lewis, K. Nielsen, S. Petroncini, M.-T. Pontes, B.-O. Schild, P. Sjöström, H.C. Søresen, T. Thorpe, Wave energyin Europe: current status and perspectives. Renewable and Sustainable Energy Review, 6 (5), 2002: 405-431.

https://doi.org/10.1016/S1364-0321(02)00009-6

[6] R. Pelc, R.M. Fujita, Renewable Energy from the Ocean. Marine Policy, 26 (6) 2001: 471-479.

[7] SETIS - Ocean Wave Energy. http://setis.ec.europa.eu/technologies/Ocean wave-energy (accessed, 17 Nov. 2019)

[8] H. Titah-Benbouzid, M. Benbouzid, An Up-toDate Technologies Review and Evaluation of Wave Energy Converters. International Review of Electrical Engineering-IREE, 10 (1), 2015: 52-61. https://doi.org/10.15866/iree.v10i1.5159

[9] T. Aderinto, H. Li, Ocean Wave Energy Converters: Status and Challenges. Energies. 11 (5), 2018: 1250, 1-26.

https://doi.org/10.3390/en11051250
[10] M. Nazari, H. Ghassemi, M. Ghiasi, M. Sayehbani, Design of the Point Absorber Wave Energy Converter for Assaluyeh Port. Iranica Journal of Energy \& Environment, 4 (2), 2013:130-135.

https://doi.org/10.5829/idosi.ijee.2013.04.02.09

[11] E. Rusu, F. Onea, Estimation of the wave energy conversion efficiency in the Atlantic Ocean close to the European islands. Renewable Energy, 85, 2016: 687-703.

https://doi.org/10.1016/i.renene.2015.07.042

[12] C.P. Nwilo and T.O. Badejo, "Impacts and management of oil spill pollution along the Nigerian coastal areas", Department of Survey \& Geoinformatics. University of Lagos, Lagos, Nigeria, 2005.

[13] C. Pianca, P. Mazzini, E. Siegle, Brazilian Offshore Wave Climate Based on NWW3 Reanalysis. Brazilian Journal of Oceanography, 58 (1), 2010: 53-70.

https://doi.org/10.1590/S167987592010000100 $\underline{006}$

[14] J. Herbich, Handbook of Coastal Engineering. McGraw-Hill, 2000.

[15] J. Brooks, Elsevier Ocean Engineering Book Series; Wave Energy Conversion. Elsevier, Amsterdam, 2003.

[16] Cruz, J. Ocean Wave Energy: Current Status and Future Perspectives. Springer, Berlin, 2008.

[17] S, Barstow, G. Mørk, L. Lønseth, J.P. Mathisen, (2009). World Waves Wave Energy Resource Assessments from the Deep Ocean to the Coast. Proceedings of the $8^{\text {th }}$ European Wave and Tidal Energy Conference, Uppsala, Sweden, 7-10 September, 2009, pp.149-159.

[18] Data Source: www.en.climate-data.org 